\title{
Is there such a thing as "Grammaticalization?"
}

\author{
Brian D. Joseph \\ The Ohio State University
}

\section{Introduction}

Modern Greek is a language that figured in early discussions of grammaticalization, for among the examples that Antoine Meillet used in his 1912 work in which the term "grammaticalization" appears for the first time is the development of the Modern Greek future tense marker $\theta a$ ultimately from an earlier collocation of a full verb of volition and a subordinating element Өélo (hi)na. It is thus fitting that an examination of the origins of two grammatical morphemes in Modern Greek - the very future marker that Meillet referred to and a set of innovative weak subject pronouns - allows for the testing of some claims that have been made within the context of what has come to be known as "grammaticalization theory", specifically with regard to where weak subject pronouns come from and more generally with regard to where grammatical morphemes come from and what the nature is of the process or processes by which they arise.

There is a vast literature on these topics now, which can only briefly be touched on here, but most of it falls within the framework of grammaticalization theory. The particular cases to be discussed here from Greek are important for this framework, for they provide a basis for a critique of several of the framework's most basic tenets. In this way, some of the criticisms leveled here at grammaticalization theory echo ones made elsewhere, e.g. by the other papers in this volume, though the data base here is different and thus the range of language developments that grammaticalization theory and grammaticalization theorists must answer for is thereby expanded.

A few basics on grammaticalization are in order. Everyone agrees that the term refers to the phenomenon in which forms that at one stage of a language have fairly 
concrete lexical meanings and functions come to have more abstract grammatical uses and meanings at a later stage. As Traugott \& Heine (1991, p. 2) note, Meillet 1912 defined grammaticalization "as the evolution of grammatical forms (function words, affixes, etc.) out of earlier lexical forms".

Some standard examples of such a development can be cited here. The Old English noun lic 'body' is the source of the Modern English suffix -ly in denominal adjectives, as in man-lic 'body of a man, likeness of a man' giving rise to manly. Somewhat parallel to this, the Latin ablative mente 'with a mind' has become the French adverbial suffix -ment, presumably through the medium of phrases in which doing something with a particular frame of mind described the manner in which it was done, thus allowing for a reinterpretation of the adjective + noun manner adverbial phrase as a manner adverbial word, e.g. clara: mente 'with a clear mind' giving rise to clairement 'clearly'. In another case, the Ewe main verb bé 'say' seems to be the source of the complementizer bé 'that' which occurs with verbs of saying, perception, and cognition, so that a content word has apparently taken on grammatical value as a complementizer. ${ }^{1}$

Despite such relatively clear cases of this path of development, ${ }^{2}$ there is disagreement on the nature of this phenomenon. Especially important here is the ambivalence evident in the literature as to whether grammaticalization is a single process or instead is several processes or instead is a result of other developments, and as to what its relationship is to other mechanisms of language change.

In particular, the same authors sometimes refer to grammaticalization as a process and sometimes as several processes, but also as something that results from other mechanisms, to judge from way (see (1)) Heine \& Reh, 1984 refer to it as an "evolution" and Bybee et al., 1994 refer to it as "a long chain of developments". Some quotations which reflect this uncertainty as to the basic nature of grammaticalization — what can be called the "Process Question" — are given in (1): 
(1) Ambivalence on the "PROCESS" Question (all emphasis added/BDJ)

a. Lehmann, 1982, p. v — "[grammaticalization] is a process which turns lexemes into grammatical formatives and renders grammatical formatives still more grammatical" [NB: a virtually identical definition is given in Lehmann, 1985, p. 303]

b. Heine \& Reh, 1984 — "Grammaticalization is a process ... whereby linguistic units lose in semantic complexity, pragmatic significance, syntactic freedom, and phonetic substance"

c. Hopper \& Traugott, 1993, p. 2 - " "grammaticalization' ... refers to ... the processes whereby items become more grammatical through time"

d. Hopper \& Traugott, 1993, p. 72 - "grammaticalization is in some sense the process par excellence whereby structural relationships and associations among them are given grammatical expression"

e. Bybee, Pagliuca, \& Perkins, 1994, p. 4-5 — "grammaticization theory begins with the observation that grammatical morphemes develop gradually out of lexical morphemes ... the same diachronic processes [are] at work in a long chain of developments"

f. Hopper \& Traugott, 1993, p. 32 - "We attempt to answer the questions: what motivates grammaticalization in the first place, what mechanisms lead to it ...."

g. Heine \& Reh, 1984 - "Grammaticalization is $a[n] . . . ~ ' e v o l u t i o n ' . . . "$

Related to the "process question" and especially to the issue of whether it is a cause or an effect is the relationship of grammaticalization to other recognized mechanisms of change. Here too, some ambivalence in the literature is evident, as the quotations in (2) indicate:

(2) Relationship of Grammaticalization to other MECHANISMS of language change. 
a. Traugott \& Heine, 1991, p. 3 - "How can we distinguish grammaticalization from language change? The answer is that grammaticalization is a kind of language change"

b. Traugott \& Heine, 1991, p. 7 - "A number of mechanisms of language change have already been alluded to as being relevant to grammaticalization. This is hardly surprising if indeed grammaticalization is a subset of phenomena occurring in change."

c. Hopper \& Traugott, 1993, p. 60-1 — "reanalysis and analogy are the major mechanisms in language change. They do not define grammaticalization, nor are they coextensive with it, but grammaticalization does not occur without them."

It is particularly striking just how vague the wording is in these characterizations, e.g. "subset of phenomena occurring in change", "relevant to grammaticalization", etc. It is not clear, for instance, whether Hopper \& Traugott think of grammaticalization as something parallel to other mechanisms of change or instead as something caused by these other mechanisms, which they recognize as including at least "metaphorical transfer ..., metonymic transfer ..., reanalysis ..., and analogy”. This point becomes important later on when the discussion turns to the role that analogy can play with regard to an apparent case of grammaticalization.

Another crucial tenet in most accounts of grammaticalization is the notion of "unidirectionality", which holds that movement is always from less grammatical to more grammatical on the "cline" of grammaticality, from concrete meanings to abstract meanings. Thus, the direction of development is claimed always to be from free word to clitic, from clitic to affix, from content morpheme to function morpheme, etc., "viewed as a linear and irreversible process" (Herring, 1991, p. 253). This claim is generally presented as a principle but is actually more like a hypothesis, something subject to verification and empirical testing. 
There is an important connection between the claim of unidirectionality and the "process question" asked above. In particular, a constraint requiring movement only in one direction could be entertained if grammaticalization is a separate and distinct process or mechanism, since other processes or mechanisms of change seem not to be constrained in that way; that is, other recognized mechanisms of change, especially sound change, analogy, or reanalysis, do not seem to be subject to a constraint like unidirectionality - in sound change, for instance, both $\mathrm{t} \longrightarrow \mathrm{d}$ and $\mathrm{d} \longrightarrow \mathrm{t}$ are possible, though different conditions may favor one direction over the other. Thus, if grammaticalization is a process in and of itself, a mechanism of change that is separate and distinct from other mechanisms of change, then it could in principle be subject to a constraint like unidirectionality, since whatever governs it is independent of these other mechanisms. On the other hand, if grammaticalization is the result of the workings of other mechanisms of change, then unidirectionality, if a valid generalization to make concerning grammaticalization changes, would have to fall out from the behavior and nature of these other mechanisms. Thus the process question and the unidirectionality question are inextricably tied up with one another.

\section{Case Study \#1 - Weak Subject Pronouns in Modern Greek}

With all the preceding as background, attention can be turned to the first case study, the development of weak subject pronouns in Modern Greek, for it permits an examination of some of these crucial questions about grammaticalization. Subject pronouns are essentially grammatical morphemes, so where they come from is an issue for grammaticalization theory. As it happens also, the forms in question also present a number of interesting issues in their own right, both in terms of their synchronic status and with regard to their historical development. A full study of the synchrony and diachrony of these forms is to be found in Joseph (Forthcoming), but the crucial aspects of the account can be reported on here more briefly. 
The particular forms at issue are the weak nominative pronouns of Modern Greek, given in (3); they are distinct from the accusative only in masculine forms and for most dialects in the feminine plural too):

(3) Weak Nominative (Subject) Pronouns of Modern Greek

$\begin{array}{llll}\text { MASC.SG } & \text { Fos } & \text { FEM.SG } t i & \text { NTR.SG to } \\ \text { MASC.PL } t i & \text { FEM.PL tes } & \text { NTR.PL ta }\end{array}$

In earlier stages of Greek, specifically by the early Post-Classical period (so-called "Hellenistic Greek"), there was a nominative 3rd person pronoun, e.g. the masculine singular autós, which itself derived from an earlier demonstrative pronoun, and this pronoun is the ultimate source of the forms in (3). Thus, at first glance, the development of tos from autós, for instance, would seem to present a perfectly ordinary case of grammaticalization; however, it is far from that.

The forms in (3) actually present a number of issues pertaining to their synchronic analysis, and these turn out to be of interest with regard to the nature of the developments that led to their creation. In particular, there is uncertainty as to what they are — are they argument-filling pronouns, agreement markers, or what? Also, they interact in interesting ways with the Null Subject ("Pro-Drop") Parameter (Jaeggli \& Safir, 1989, based on "Subject Requirement Constraint” of Perlmutter, 1971), as it is realized in Greek, and thus can potentially reveal something important about Pro-Drop (and parameters in general) universally.

In addition, these forms present several general diachronic questions, as to how they arose, how weak subject pronouns in general arise, and what connection, if any, there is diachronically between Pro-Drop and the creation of weak subject pronouns. More particularly, though, these synchronic and diachronic concerns regarding tos (etc.) have a direct bearing on four claims that have been made by Haiman, 1991, working primarily with Germanic and Romance data, and one by Hopper \& Traugott, 1993, regarding the origin of weak subject pronouns. First, Haiman claims that only 
languages with a Verb-Second constraint become non-Pro-Drop languages. Second, he claims that bound clitics are not generated ex nihilo diachronically, stating rather that they were once "full" pronouns, with argument status. Third, he claims, based mainly on his interpretation of Germanic evidence, that second person forms play a leading role in subject-pronoun formation. Finally, he claims that inverted word order is crucial in this process by which subject pronouns arise. In addition, Hopper \& Traugott (1993, p. 128-9) make a strong claim concerning the origin of grammatical items in general, stating that "to date there is no evidence that grammatical items arise full-fledged, that is, can be innovated without a prior lexical history".

As becomes clear below, the facts from the development of Greek tos contradict each of these claims.

Haiman draws an explicit connection between the development of subject pronouns and a language's status as a non-Pro-Drop language. Therefore, in order to test these essentially diachronic claims properly, the synchronic nature of a language with regard to the Pro-Drop parameter is crucial. Therefore an exploration is needed into the nature of Pro-Drop in general and how it is realized in Greek, and this aspect of the investigation is taken up in the following section.

\subsection{Excursus on Pro-Drop}

Pro-Drop is the phenomenon that describes languages which allow phonologically null subjects (“"pro’) in tensed sentences. Greek and Spanish are generally held to be typical Pro-Drop (or "null subject") languages, whereas English and French are generally held to be typical non-Pro-Drop languages, requiring phonologically realized subjects in tensed sentences. In addition, a language's Pro-Drop status correlates with absence/presence of nonreferential expletive subjects in certain constructions, such as with "weather" predicates. Some sentences showing these properties from these languages are given in (4): 
(4) a. Greek: emís/Ø perpatúsame

we walk/1PL.IMPF

'We were walking'

b. Spanish: Juan/Ø vio ese film

'Juan/He saw that film'
// *aftó / Ø vréxi

it/NTR rains/3SG

// 'It is raining'

// *Esto/Ø llueve

'(It) is raining'

c. French: Ils/* $\varnothing$ parlent 'They are speaking' // Il / $\varnothing$ pleut 'It is raining'

d. English: Juan/* $\varnothing$ saw that film $\quad / / \quad \mathrm{It} /{ }^{*} \varnothing$ is raining.

The Pro-Drop languages can have a null subject (indicated by $\varnothing$ in (4)) and do not require an expletive subject, even to the point of blocking one altogether, while the non-Pro-Drop languages require an overt subject, expletive or otherwise.

Despite the evidence of $(4 \mathrm{c})$ and $(4 \mathrm{~d})$, there are indications that the non-Pro-Drop character of French and English is not valid for all finite verbs in the language; in particular, Morin, 1985 has analyzed the French deictic predicates voici/voilà 'Here is/are; there is/are!' as subject-less finite verbs, due to parallels they show in distribution and behavior with ordinary finite verbs. As such, they violate the usual non-pro-drop character of French, since sentences such as those in (5):

a. Voilà une preuve d' intelligence

voilà a proof of intelligence

'Here is a sign of intelligence!'

b. La voilà

her/OBJ voilà

'Here she is!'

have a finite tensed predicate in voilà but no overt subject; une preuve in (5a) and la in (5b) are objects, not subjects. Such facts suggest that the pro-drop parameter is set on a lexically particularized or construction-specific basis, rather than being generally valid for all predicates in the language. 
The same conclusion is indicated by the facts of certain English predicates. For instance, the idiomatic expression Beats me, in the meaning 'I don't know', typically, and perhaps categorically for some speakers, shows the absence of a subject (though not with a preceding "heavy" adverbial of some sort), despite the fact that beats is a tensed finite verb, as in (6):

(6) Qn: Do you know what the answer to question 20 is?

Ans.: Beats me! / *That/??It beats me! / (That/?It) sure beats me! /

*Right now beats me!

Similarly, the Ain't no ... construction, which is nonstandard but used even by some speakers of standard English for emphasis, typically, and again perhaps even categorically for some speakers, occurs with no overt subject, although an expletive is possible in some instances:

a. Ain't no way I can finish this paper in time! / There ain't no way ...

b. Ain't nobody who can play dead like me, Ernest [uttered by Meryl Streep's character, in the movie Death Becomes Her]

The upshot of these facts about Pro-drop is the recognition that it may be relativized over different predicates, suggesting some lexical conditioning of the parameter setting for pro-drop (or at least construction-specific setting); whether this is a direct effect or an indirect one (see Joseph, 1994 for some discussion) is irrelevant here.

\subsection{Modern Greek tos (etc.)}

Some specifics are now in order regarding the weak subject pronouns, which are referred to here as tos (etc.), using the masculine singular form as a cover term, largely because the masculine singular is the only part of the paradigm where the form is always distinct from the accusative. As indicated in (8), these are actually quite restricted, occurring generally in two, and only two, constructions, with the deictic 
predicate ná 'here is/are!' and the locative interrogative pún 'where is/are?' (with voicing of $t \rightarrow d$ induced by final $n$ ); the use of tos with other verbs is ungrammatical: ${ }^{3}$
a. ná tos 'Here he is!', ná ta 'Here they are', etc.
b. pún $d o s$ 'Where is he?', pún $d i$ 'Where are they?/Where is she?', etc.

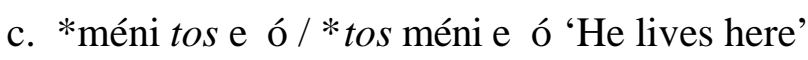
d. *févji tos tóra / *tos févji tóra 'He is leaving now'

Any account of the diachrony of tos (etc.) thus has to address the limited distribution these forms show.

Besides the pattern with tos, the predicates ná and pún occur in a number of other patterns, as given in (9); some of these are crucial to the account given below for the origin of the weak subject pronouns (\% indicates variability from speaker to speaker as to acceptability):

a. ná + ACCUSATIVE of full NP, e.g. ná ton jáni "Here's John"

\%pún + ACCUSATIVE of full NP, e.g pún ton jáni "Where's John?"

b. ná + NOMINATIVE of full NP, e.g. ná o jánis "Here's John"

\%pún + NOMINATIVE of full NP, e.g. pún o jánis "Where's John?"

c. ná + ACCUSATIVE of WEAK PRONOUN, e.g. ná ton "Here he is"

\%pún + ACCUSATIVE of WEAK PRONOUN, e.g pún don "Where is he?"

d. ná by itself, e.g. ná "Here!", or pú íne o jánis? Ná. "Where is John? Here (he is)!"

*pún by itself, e.g. Ná o jánis. *pún "Here's John! Where is he?" (vs. pú "Where?”, OK alone)

Since ná and pún occur in and determine complete sentences together with nominal elements, they appear to be predicates, and in fact there is evidence that they are to be analyzed as verbs. In ná + ACCUSATIVE type of (9a), the occurrence of accusative case is expected if ná is an imperative, and the placement of the weak object 
pronoun after it is exactly as it would be with an imperative (compare kíta ton 'Look-at him!). Moreover, dialectally, the ostensible "plural" form náte is reported (Thumb, 1910; Thavoris, 1977), with plural imperative ending -te (cf. éla 'come! (SG)' vs. eláte 'come! (PL)'), and this form gives overt evidence of the analysis of ná as verb, and more specifically, an imperative, at least in those dialects. In the $n a ́$ + NOMINATIVE type of (9b), the occurrence of nominative case can be accounted for, if it is assumed that nominative case (at least within a Government and Binding approach to syntax) is typically assigned by a verb with an AGR(eement) node, so that within such a framework, ná in ná + NOMINATIVE presumably has AGR and consequently is a verb.

As for pún, its ostensible composition is / pú $+-n /$, where the pieces can be identified as as the locative interrogative word pú 'where?' + - $n$, a reduced form of íne 'is/are', the 3SG/PL form of 'be', and this segmentation is both supported by the semantics of pún and in accord with the intuitions of many speakers. Thus, pún, under this analysis, contains at least a piece of a verb, consistent with treating it in toto as a verbal unit. Moreover, for those speakers who find $(9 \mathrm{a} / \mathrm{c})$ to be ungrammatical, the absence of accusative case with pún is consistent with this analysis, inasmuch as the complement of the verb 'to be' in Greek is never in the accusative case; speakers for whom $(9 \mathrm{a} / \mathrm{c})$ are acceptable clearly have reanalyzed pún as independent of ine.

With all these preliminaries out of the way about the constructions in which the ostensible "weak subject/nominative pronouns" occur, it is possible now to show clearly that these forms are in fact weak nominative pronouns. The best evidence for this classification is morphological in nature: as (10) shows, these forms have the same inflexional endings as the nominative strong 3rd person pronouns:

$$
\text { STRONG "WEAK" }
$$

SG aft-ós 'he' / aft-i 'she' / aft-ó 'it' t-os 'he' / $t-i$ 'she' / t-o 'it'

$\mathrm{PL} a f t-i \quad$ aft-és aft-á $t-i \quad t$-es $t-a$ 
Moreover, as (11) shows, there is a parallelism between the strong-weak pairs in the accusative and the strong plus ostensible-weak forms in the nominative as well, such that the weak forms equal the strong forms minus their initial $a f$ - (except, in some dialects, in FEM.ACC.PL):

ACCUSATIVE

\section{STRONG}

M aftón 'him' :

$\mathrm{F}$

$\mathrm{M}$

$\mathrm{N}$

$\mathrm{F}$

NOMINATIVE

STRONG "WEAK"

WEAK

aftós 'he' : tos 'he'

$\mathrm{N}$ aftó 'it' : to 'it' :: aftó 'it' : to 'it'

F aftín 'her' : tin 'her' :: afti 'she' : ti 'she'

M aftús 'them' : tus 'them' :: afti 'they': ti 'they'

$\mathrm{N} \quad$ aftá 'them' : $\quad$ ta 'them' :: aftá 'they' : ta 'they'

F aftés 'them' : tis 'them' :: aftés 'they': tes 'they'

(dialectally: tes)

Furthermore, there is the syntactic evidence shown in (12), namely that just as the weak accusatives participate in "argument doubling" of a direct object, as in (12a), so too can the ostensible weak nominative forms "double" full NPs in the constructions they occur in, as in (12b/c):

a. ton vlépo ton jáni

him/WEAK.ACC see/1SG the-John/ACC

'I see John' (literally: “him I-see the-John”)

b.. ná tos o jánis

here-is he the-John/NOM

'Here's John!' (literally: "Here he is John!”)

c. pún dos o jánis

where-is he the-John/NOM

'Where is John?' (literally: “Where is he John?”) 
It may be concluded, therefore, that the ostensible weak subject pronouns are indeed just that — weak pronominal forms that mark subjects.

It is possible to go farther than that, however, in the categorization of these forms. One might think that weak subject pronouns are necessarily clitic elements, that is to say, phonologically dependent word-like elements, but there is evidence that they are in fact affixes and not clitics. Drawing on the distinction made by Zwicky \& Pullum, 1983 and by Zwicky, 1985, and the criteria they establish for distinguishing between these two types of elements, it can be argued that in present-day Greek, tos (etc.) are best treated as affixes, though admittedly there is some room for ambiguity in the judging of the facts. First of all, tos (etc.) are highly selective in what they can attach to, occurring only with ná and pún and nothing else, and they show strict ordering requirements vis-à-vis the elements they can occur with (ná tos but *tos ná, pún dos but *tos pún), both properties more characteristic of affixes than clitics. At the same time, though, they show no semantic or morphophonological idiosyncrasies, and the combinations they occur in are fully compositional in their semantics, the sort of situation one tends to find with clitics rather than affixes.

What seems to be decisive in the classification of these forms is the evidence of post-nasal voicing in Greek. The initial $t$ - of tos (etc.) is voiced after the final $-n$ of pún, giving pún dos, a development that is in keeping with general tendencies in Greek to voice stops after a nasal, but is in fact a reason for differentiating tos from true clitics in the language. In particular, other evidence suggests that after a nasal-final host, only the pronominal elements that show other characteristics of affixhood undergo the voicing whereas those that show nonaffixal characteristics do not undergo voicing. Thus the object pronouns are affix-like in showing idiosyncrasies, high selectivity, strict ordering, etc. (see Joseph, 1988, 1990) and are voiced post-verbally after the imperative singular of káno 'do, make', the only context where a weak object pronoun occurs after a nasal-final host in the standard language, e.g. /kán tu mja xári/ 
'do for-him a favor' $\longrightarrow[\operatorname{ká}(n) d u$... $] .{ }^{5}$ On the other hand, the possessive pronoun $t u$ 'his' in ton anӨrópon tu 'of his men' (literally, "of-the-men/GEN.PL of-him”) does not undergo voicing for many speakers; this failure of voicing to occur shows that not all sequences of nasal-plus-voiceless stop undergo voicing. The $t u$ in ton an $\theta$ rópon tu is a possessive pronoun, an element which can move around within the noun phrase both $o$ kalós fílos $t u$ 'the good friend of-him and o kalós tu fílos the good of-him friend' are acceptable for 'his good friend' — and is thus analyzable as a true clitic; since it does not undergo voicing, one can hypothesize that (true) clitics cannot be voiced in a post-nasal environment. Thus, since the $t$ - of tos can, and in fact must, be voiced in pún dos, it would follow that it is not a clitic.

Still, the absence of idiosyncrasies with tos can be interpreted to mean that tos has only recently acquired affixal status, with that status coming just at the point at which the voicing became possible with it. It is reasonable, therefore, to assume that it entered the language as a clitic and has undergone change of status into an affix. Movement from clitic to affix is a well-attested path of historical development, so if tos (etc.) started out as clitics, their movement into affixal status is not surprising.

The problem that is posed by the constructions with tos, especially at the point at which they entered the language as subject clitics, now becomes clear. Even though Greek is a Pro-Drop language, there are two constructions in which weak pronouns occur unemphatically. The weak form can be omitted with ná, though its occurrence is preferred, but with pún, omission of the tos, when there is no full NP, is impossible. Therefore these facts constitute a lexical or construction-specific exception to ProDrop in a language that is otherwise an ordinary Pro-Drop language. This is the reverse of the situation with French voici/voilà, where those predicates allowed ProDrop in a language that is otherwise an ordinary Non-Pro-Drop language. Greek, therefore, presents surface sentences with an obligatory weak subject pronoun (e.g. the 
pún dos construction) and thus is not a "canonical" Pro-Drop language, though in a sense, neither is it a a canonical Non-Pro-Drop language.

\subsection{The Diachrony of tos (etc.)}

Reference has been made to the point at which tos entered the language, so it is appropriate now to consider the diachrony of these forms. It is here that the test for Haiman's claims and for certain aspects of grammaticalization theory comes into play.

The starting point is the late Classical and early post-Classical pronominal system (see Dressler, 1966), with a strong-weak distinction only in the non-nominative cases (accusative, dative, genitive), in all persons, e.g. strong third person accusative singular masculine autón versus weak hé. However, for nominative forms, no persons showed a weak vs. strong contrast; rather, strong vs. zero was the relevant contrast and that held for 1 st and 2 nd person only, so that there was no 3 rd person strong pronoun. In the Koine period, autós, previously a demonstrative 'this', began to be used as 3rd person (here, singular masculine) nominative subject pronoun, thus extending the strong vs. zero contrast in the nominative of 1 st and 2 nd person to 3 rd person. Also in the Post-Classical period, an accusative pronoun tón (e.g., masculine singular) was beginning to emerge; originally, e.g. in Homeric Greek, this form was a demonstrative, and it became a definite article by the Classical period, though some purely pronominal uses are still to be found in Classical Greek and they recur in the Koine. ${ }^{6}$ This emerging accusative ton fit into the system well as the weak counterpart to the inherited strong form autón, supplanting older hé. What was missing was a weak nominative form corresponding on the one hand to the weak accusative form ton and on the other to the strong nominative form autós.

What made it possible for the weak nominative form to emerge, it seems, is the entry into the language of a construction with the deictic element ná, which arose in Middle Greek. Whatever its origin, and the etymology of this form is disputed, with 
some deriving it from an earlier Greek source and others seeing it as a borrowing from Slavic, its original syntax would have been to govern an accusative, and most likely a weak accusative form (see Joseph, 1981, 1994). If ná is a borrowing from Slavic, accusative would be likely given that a syntagm of deictic particle plus accusative is widespread in South Slavic (cf. Schaller, 1975), as in Bulgarian eto go 'Here he is' (literally: "Here-is him/ACC"). But even if ná is an inherited form, from earlier Greek e:ní, abstracted out of e:níde (= e:n 'behold!' + ide (imperative of 'see')), as suggested by Hatzidakis (1905, II, pp. 100, 400, reiterating a suggestion he first made in 1889 in the inaugural issue of the journal Athe:nâ), accusative would be the likely case of the complement, given that the expected syntax of ide as imperative of 'see' is that it would govern an accusative object.

Several innovations in the ná construction led to the emergence of tos from an original syntagm with accusative. The first step must have been that a construction with $n a+$ nominative, presumably of a full NP, became possible. This novel construction was no doubt aided by two facts about Greek: there are nouns in Greek, neuters to be exact, with the same form for nominative and accusative — so that ná to

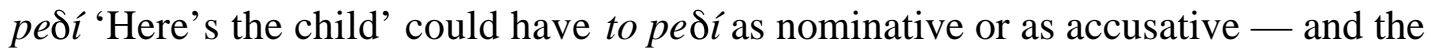
semantics of these deictic sentences would favor an interpretation of the argument of ná as a subject, and thus as a nominative. Next, assuming that the strong pronouns (MASC.NOM.SG aftós, MASC.ACC.SG aftón, etc.), which otherwise have the same distribution as ordinary nouns, could occur with ná, and further that these different constructions (ná + NOM and ná + ACC) would have coexisted as alternants, the stage would have been set for a four-part proportional analogy, as in (13), that would yield a weak nominative subject form tos:

$$
\text { ná aftón } \quad: \text { ná aftós } \quad: \text { ná ton }: \text { ná } \mathrm{X}, \mathrm{X} \rightarrow \text { tos }
$$

ACC.STRONG NOM.STRONG ACC.WEAK NOM.WEAK


This analogical account for the appearance of tos entails rejecting the possibility of treating it as merely a phonologically reduced form of autós (pronounced [aftós] by the Hellenistic period, e.g. via ná aftós $\longrightarrow$ ná tos. There are several reasons for rejecting a purely phonological account of the emergence of tos, in the way of problems that such an account is hard-pressed to overcome. First, one would have to ask why the result is not doubly accented, i.e., ná tós*, instead of the single accent attested; admittedly the assumption of an accentual readjustment to eliminate double accentuation is not difficult, and it could conceivably be a concomitant of a reanalysis of tós as an affix, but it is something extra that is needed under a purely phonological account of the emergence of tos. Second, if the starting point for tos were really aftós, one has to ask how the $-f t$ - cluster came to be reduced to $-t$-, since this is not a regular phonological process in the history of Greek. In this case, though, there is a pronominal form atós that occurs as the third person strong nominative pronoun in Post-Classical Greek, beside aftós; whatever the source of atós, and it may well have been an irregular reduction of aftós, it would seem that it could provide the basis for the emergence of tos, via a vowel contraction and resegmentation (i.e., ná atós $\longrightarrow$ ná 'tos). However, such a source does not solve the double accent problem, nor does it rule out a parallel development involving aftós, to something like ná 'ftós* which could reasonably be expected to have competed with ná 'tos; that is, such an account would also have to explain why ná 'ftós* disappeared, again not an unreasonable development but again something extra forced by an insistence on a phonological account for tos. Furthermore, and perhaps most problematic, an account that starts with atós does not generalize to dialectal forms of the deictic, such as Ionian éntos, with a different non-vowel-final deictic element (en, perhaps from Ancient Greek $e: n$ or from the verb 'be'), for if the source were é:n atós, then the expected outcome for Ionian would be the nonoccurring **énatos instead of the attested éntos. 
Invoking analogy as the mechanism of change responsible for tos thus provides a more compelling account. The double accent problem is a non-problem, since the analogy in based in part on the weak accusative pronoun, which is itself unaccented, guaranteeing that the result of the analogy would also be unaccented. In addition, since atós is not involved, there is no reason to worry about competing syntagms and how the competition would have been resolved, and no special assumptions are needed to account for Ionian entos.

Moreover, the plausibility of this analogical account is enhanced by a parallel with a strikingly similar development in Hittite. Hittite shows a three-way contrast in subject pronominals, illustrated with animate singular forms: ${ }^{7}$ apa:s (strong) vs. -as (weak) vs. $\varnothing$ (weakest), where the distribution is based on a grammatical property, verbal argument structure, since the weak nominative form generally occurs only with unaccusative intransitive verbs and $\varnothing$ with transitives. According to Sturtevant, 1939 (see also Anttila, 1972; Jeffers \& Zwicky, 1980), the weak nominative forms are old, of Proto-Indo-Hittite age and thus inherited in Hittite. However, there is no comparative evidence of any sort anywhere among Indo-European languages that would point to a reason to reconstruct them for Proto-Indo-European. Thus, according to Garrett $(1990,1996)$, the weak subject pronouns are a Hittite innovation, and the process by which they arose was analogical. Since the weak accusative pronouns, e.g. animate singular -an, are presumed to be inherited, inasmuch as they are found in some form in various Indo-European languages, Garrett suggests that the inherited opposition in Hittite of $*_{0}$-stem accusative in $*_{-} \mathrm{O}-\mathrm{m}\left(\right.$ Hittite - an) to $*^{\mathrm{o}-\mathrm{stem}}$ nominative in $*_{-o-s}($ Hittite $-a s)$ was a model for extension into the weak pronouns, with a weak subject pronoun being created after the pattern of $* \mathrm{o}$-stems (exemplified with the noun atta- 'father'):

$\begin{array}{llllll}\operatorname{attan}: & \operatorname{attas} \quad: \quad \text { an } & & \mathrm{X}, \quad \mathrm{X} \rightarrow & \text { as } \\ \text { NOUN/ACC } & \text { NOUN/NOM } & & \text { WEAK.ACC } & & \text { WEAK.NOM }\end{array}$


The analogy that occurred in Hittite exactly parallels the one posited here for Greek in terms of the creation of a new form with a grammatical value. There are differences in the way these forms are used in their respective systems, in that the Hittite ones are used with intransitive predicates only, whereas the Greek tos occurs just with the two predicates noted above. Still, the parallel does show that under similar sorts of stimuli and internal pressures, languages can respond in the same way, suggesting a naturalness to the developments posited here for Greek.

It may be concluded, therefore, that the Modern Greek weak subject pronominal tos, an innovative grammatical form, arose as an analogical creation, most likely in the Medieval period. ${ }^{8}$

\section{4. tos versus Haiman — The Nature of Grammaticalization}

With the path by which tos arose now established, along with the way the form fits into the overall morphological and syntactic patterns of the language, the relevance of these developments for Haiman's claims and for more general considerations regarding grammaticalization can be addressed.

It turns out that none of Haiman's claims can be maintained in the face of these developments with tos.

Contrary to his claim that only languages with a Verb-Second constraint become non-Pro-Drop languages and develop subject pronouns, Greek has developed a subject pronoun in tos, and yet it is not a non-Pro-Drop (Haiman's "type A") language in general. Nor does Greek have a Verb-Second constraint, but rather has relatively free ordering of major constituents in a sentence. Moreover, the two constructions which show non-Pro-Drop characteristics and have tos as a weak subject pronoun, ná tos and pún dos, are not subject to a V/2 constraint, but rather are verb-initial constructions. 
Second, contrary to Haiman's claim that bound clitics are not generated ex nihilo diachronically but were once "full" pronouns, with argument status, there is no evidence whatsoever that tos (etc.) was ever a "full' pronoun, with argument status" at an earlier stage of Greek. Rather, as argued above, these forms did not arise as a reduction of a full form (whether phonologically or via morphological resegmentation) but as the result of an analogical extension of an already-existing pattern. Counter to the claim of Hopper \& Traugott, 1993 mentioned above, this emergence of tos is as close to having no "prior lexical history" as one could ever expect to find, with emphasis on "lexical".

Third, contrary to Haiman's claims that second person forms play a leading role in subject-pronoun formation, in the case of Greek tos, the second person played no role, since these new Greek weak subject pronouns are only third person. Admittedly, deictic ná in its earliest use seems to have been an imperatival form, specifically second person (recall the dialectal plural form náte, with the second person plural marker -te, discussed in $\$ 2.2$ ), and that imperatival form figured in the scenario by which tos arose; however, at some point, ná must have been reanalyzed as something other than an imperative, in order to explain the occurrence of nominative case forms with it.

Finally, contrary to Haiman's last claim, that inverted word order is crucial in the process of creation of weak subject pronouns, it must be noted that although the arguments of ná always follow it, this word order cannot be considered inverted, given the generally free ordering that Greek shows.

Similarly, Hittite counters each of these claims too, in much the same way as Greek does, assuming Garrett's account to be right.

More generally yet, most views about the origin of subject pronouns work with some version of a phonological reduction model, but significantly, all start from already existing free words or clitic sequences. That is, most treatments of the 
development of clitics, especially clitic pronouns, focus on the phonological reduction of free words as the source, especially in prosodically weak contexts, sometimes via deaccentuation, and often affecting elements that are semantically weak as well (so Steele, 1977; Givón, 1979; Jeffers \& Zwicky, 1980; Haiman 1991). Steele and Haiman specifically discuss the creation of clitic subject markers, in Uto-Aztecan and various Romance dialects respectively. Jeffers \& Zwicky suggest that reinterpretation (reanalysis) and metathesis can be additional ways in which certain types of clitics, especially those positioned word-internally (so-called "endoclitics"), can arise, but, crucially, these developments start from clitic sequences and are really only accounts of the repositioning of clitic elements.

Thus, the analogical process for the creation of tos (and Hittite as), especially in the (presumed) starting point as a true clitic, involves a means by which new clitic (or clitic-like) material comes into being other than by the relatively common downgrading of free words (by far the most common way), often with semantic bleaching, or by the supposedly rare but nonetheless well-attested upgrading of affixes to free words (see Janda, this volume, for discussion and examples). This process is very different from the presumed path for the creation of subject clitics in the relatively well-studied cases from Romance languages. Therefore, sources of weak subject pronouns via a process other than phonological (and semantic) reduction need to be recognized.

Thus this apparently straightforward case of ordinary, garden-variety "grammaticalization" via phonological reduction turns out to be part of a very different story once subjected to a closer inspection. Indeed, even more telling is what the development of tos says about grammaticalization in general. It means that at least some grammatical morphemes have developed through the workings of well-known - and independently motivated and documented - processes of change, in particular analogy, and thus that nothing special needs to be invoked to account for the appearance of weak subject pronouns in Greek. Specifically, no sort of 
"grammaticalization" as a process in and of itself is needed to lead to the form itself or to its place in the grammar. Therefore, since grammaticalization need not be invoked in all cases of the creation of grammatical morphemes, it can be speculated that perhaps it does not need to be invoked in any case, since other well-known forces of linguistic change, such as phonetic change and reanalysis, as well as analogy, would seem to be sufficient to bring on the results often cited under the rubric of grammaticalization. Certainly, the strongest theory to pursue here would be one that restricts the number of processes posited in change, rather than one that expands that number. In a sense, then, tos shows that there need not be any such "thing" as grammaticalization, certainly not as a process of change, though it could be used to label the ultimate outcome of genuine processes (see also Campbell, Janda, and Newmeyer, this volume).

\section{Case Study \#2: The tha Future}

As noted in the introduction, Greek offers a second relevant case study, namely the developments leading to the Modern Greek prefixal future with the marker $\theta a$, some examples of which, together with other pieces of the verbal complex, are given in (15):

a. $\theta$ a rráfo

FUT write/1SG

'I'll be writing'

b. $\theta \mathrm{a}$ su $\quad$ ráfo

\section{FUT you/GEN write/1SG}

'I'll be writing to you'

c. Sen $\theta$ a rráfo

NEG FUT write/1SG

'I won't be writing'

d. Sen $\theta \mathrm{a}$ su $\quad$ ráfo 


\section{NEG FUT you/GEN write/1SG}

'I won't be writing to you'

This future marker in the modern language at least is best analyzed as a true prefix, based (as with tos above) on the criteria for classification proposed by Zwicky \& Pullum, 1983 and by Zwicky, 1985. In particular, it is clearly a bound element, since it cannot stand alone and is unaccented. More specifically, $\theta a$ is affixal since it shows a

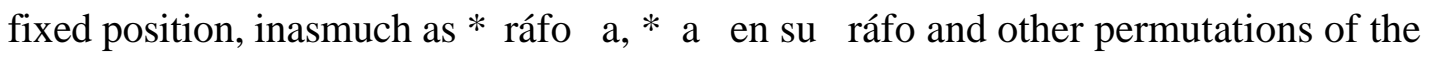
elements in (15) are all ungrammatical, and selectivity, in that it attaches only to verbs. These are both properties more usual of affixes than of clitics or free words. Furthermore, $\theta a$ shows some idiosyncratic behavior, of both a phonological and a semantic nature, that again is a characteristic more typical of affixes than of clitics. For instance, for some speakers, it triggers idiosyncratic voicing on third person weak pronouns that follow it, for these forms, which otherwise occur with initial [t-], can be pronounced with [d-] after $\theta a$, e.g. [ $\theta$ a do $\gamma$ ráfo] 'I'll be writing it' (Householder, Kazazis, \& Koutsoudas, 1964). In addition, $\theta a$ shows some special combinations with a few verbs, contracting for instance with forms of the verb 'be', e.g. / $\theta \mathrm{a}+$ íse / 'you will be' $\longrightarrow$ [ $\theta$ áse], even though the contraction of $a+i$ to $a$ is not a general phonological process in Greek - the - $a$ of the adverb kalá 'well' combines with íse to give [kalájse] not *[kaláse] 'are you well?', for instance. Finally, $\theta a$ shows idiosyncratic semantics in the expression tí $\theta a$ pí? 'What does it mean?' (literally: "What will it-say?"). All of these characteristics taken together indicate that for Modern Greek, the future marker is an affix.

However, it seems that it was not always an affix. The future marker, as noted in section 1, has provided grist for the grammaticalization mill, for the ultimate source of $\theta a$ is the Classical and early Post-Classical Greek verb of volition thélo: 'want', which occurred as a main (lexical) verb with an infinitival complement, as in (16):

(16) thélo: gráphein 
want/1SG write/INF

'I want to write'

In later post-Classical Greek, the infinitive gave way to a finite clausal replacement introduced by the subordinator hina 'that', as in (17), a process beginning in the Hellenistic period that spread on a construction-by-construction basis (see Joseph, 1978/1990, 1983 for details and bibliography):

thélo: hina grápho:

want/1SG that write/1SG

'I want to write' (literally: "I-want that I-write").

The more immediate source for the future prefix $\theta a$ is a "redeployment" of the infinitive with thélo: , coupled with a semantic shift from volitional (lexical) main verb to a more auxiliary-like and grammatical future meaning, as in (18):

thélo: gráphein

1SG write/INF

'I will write'.

As an independent verb at this stage thélo: still means 'want', a meaning and use that continues into present-day Greek (though not with an infinitival complement).

At this point, to follow essentially the account of Psicharis, 1884 and the chronology for the emergence of various future formations seen in Bânescu, 1915 (see also Joseph, 1978/1990, 1983), there began a chain of developments which ultimately led to the form $\theta a$. These developments included regular sound change, reanalysis, and analogical generalization of sandhi variants, among others. The first step was the loss of word-final $-n$ in the infinitive by regular sound change, ${ }^{10}$ which resulted in future formations as in (19):

thélo: gráphei / thélei gráphei

1SG INF

3SG INF

'I will write'

'(s)he will write' 
in which the infinitival complement came to be homophonous with the third person singular indicative form in that both ended in -ei (thus, gráphei was both 'to write' and '(s)he writes'). At that point, it seems that the future formation in the third person was reanalyzed as a combination of two third person marked forms (see Anttila 1972), with the reanalysis being evident in the extension of this new pattern with multiple inflected forms into other persons in the paradigm, as in (20):

(20) thélo: grápho:

1SG write/1SG

'I will write'

This pattern must have co-existed with the infinitival formation of (18), as both types are to be found in the same texts in Medieval Greek. ${ }^{11}$ The on-going replacement of the infinitive by finite complementation, operating on the renewed use of the infinitive in the future type of (18), and thus occurring later than the extension of the replacement process seen in (16) and (17), gave rise to an innovative type that was identical to (20) in meaning and similar to it in form other than occurring with the subordinator hína (glossed here, probably inadequately, as 'that'), and was identical in form to (17) but instead had future meaning:

(21) thélo: hina grápho:

$1 \mathrm{SG}$ that write/1SG

'I will write'

From the future types of (20) and (21), by the elimination of redundant person marking, a type developed with an invariant third person singular form $\theta e ́ l i$, which as an independent verb still means '(s)he wants', with no subordinator (from (20) or with the subordinator $n a$, from hina of (21) by regular sound changes: ${ }^{12}$

(22) a. Géli rráfo

3SG write/1SG

'I will write' 


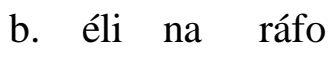

3SG that write/1SG

'I will write'

The next step was that, from (22), a reduction of $\theta e ́ l i$ occurred giving $\theta e ́$. This reduction may have been a fast speech phenomenon, since it also affected at least some forms of the independent verb 'wants' (in present-day Greek, for instance, the second person singular of (nonfuture) Aélis 'you want' is commonly reduced to $\theta e ́ s$ and reductions with other persons and numbers may be possible as well), but it gained currency most generally with only the future marker. Some modern dialects have $\theta e ́ l a$ yráfo for the future 'I will write', suggesting that the reduction may in the case of (23b) have been via a stage with $\theta e l$ 'na (elision of unstressed $-i$, and reduction of or assimilation in the resulting - $\ln$ - cluster). By whatever route, however, the future patterns in (23) resulted:

(23) a. Đé Yráfo

FUT write/1SG

'I will write'

b. Өé na rráfo

FUT

'I will write'

At some point, moreover, $\theta e$ became deaccented, though the chronology of that development is not clear.

Further developments from the formation in (23b) led to the widespread modern form $\theta a$, usually given as end point of the "grammaticalization" with the Modern Greek future. In particular, $\theta e ́$ na yráfo of (23b) underwent an irregular vowel assimilation, giving $\theta a ́$ na yráfo. Here it is relevant that some modern dialects have

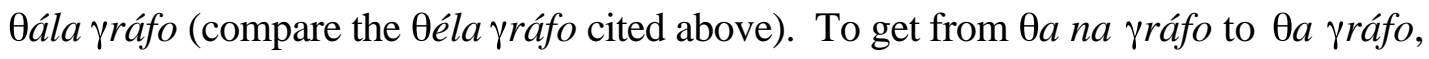
the safest assumption is that there was a variant of $\theta a$ na before a vowel-initial verb, 
such as ayorázo 'I buy', that had the form $\theta a n$, and this pre-vocalic sandhi alterant was generalized to pre-consonantal position, giving $\theta a ́$ $n$ ráfo; in this way, no irregular phonological developments need to be assumed, since contraction of $-a a$ - to $-a$ - is regular in Greek. By a similar path, this variant $\theta a ́ n$ could have yielded $\theta a$ in all contexts - the loss of - $n$ - in $\theta a n$ yráfo would be regular, and the resulting preconsonantal $\theta a$ could then have spread to pre-vocalic contexts, giving forms such as

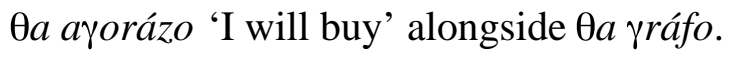

It is therefore possible to motivate all of the stages by which thélo gráphein could have yielded the Modern Greek future $\theta a$ yráfo, through the crucial intermediary stage of thélo: (hi)na grápho: Moreover, all of the necessary stages are directly attested or safely inferrable. Significantly, all of these steps involve, for the most part, perfectly ordinary and well-understood processes in language change: sound change, reduction of redundancy, and (analogical) generalization of one variant at the expense of another.

From the foregoing, it is clear that at the point at which the invariant third person singular form thélei was fixed in the future construction, there was a significant change in the construction. At that point, thélei was certainly more grammatical in nature and less lexical, despite the identity in form between it and the third person singular of the main verb of volition 'want'; in particular, it was fixed positionally, could not support clitics, ${ }^{13}$ and could not be inverted, even though in previous stages, there were fewer such limitations on the form of thélo: in the future. It is not clear when this more restricted thélei or its successors developed into a prefix, but clearly thélei was a step in this direction.

On the one hand, therefore, the development of prefixal $\theta a$ from thélo: (hi)na looks like a perfectly ordinary case of grammaticalization, with an affix developing out of a once free form by a nicely traceable progression, and so it is no accident that Meillet drew attention to this in his important early article on grammaticalization. On the other hand, though, it is possible to take a somewhat heretical view of these 
developments with regard to grammaticalization, a view that has a direct bearing on the "process" question discussed in section 1 above.

In particular, the stages that are usually taken as showing grammaticalization, especially the end stages whereby the status of future marker as nothing more than a function morpheme becomes clearest, are perhaps the least interesting as far as grammaticalization is concerned, under the view that grammaticalization is a process. That is, if grammaticalization is a process, then the changes leading to $\theta a$ are really just part of an inexorable movement towards greater grammatical form, and so the really crucial step is the initial one by which thélo: + the infinitive first began to be used as a future (= (18)); the subsequent changes just provide further ammunition, so to speak, but the critical first step is what activates the process.

On the other hand, if instead grammaticalization is not a process but rather is merely a description of the outcome, then these stages are crucial to reaching the end result of an element that is fully a function/grammatical morpheme. Significantly, though, they are not guided by some "higher force" driving them on since, ex hypothesi, there is no process of grammaticalization; rather they are just ordinary instances of phonetic change and analogy, resulting in increased separation of mainverb thélo: from what ultimately became $\theta a$.

Yet, it is well-known that speakers can lose sight of obvious connections among elements so that the increased separation of free form and bound form here does not require the positing of a special mechanism. The first part of the English verb withstand is a case in point, as opposed to the preposition with, for the original meaning of with as 'against' is preserved in the compound (literally "stand against"), but is not evident in the free form, as discussed by Kim, 1995. Other similar cases involving a separation of forms that were once clearly related include the creation of an innovative gerund hafing to, replacing having to, based on hafta (i.e. have to), despite a seemingly clear connection with the verb have (Joseph, 1992), and let's (discussed 
both by Joseph, 1992 and by Hopper \& Traugott, 1993, p. 10-13), which has moved away from its let $+u s$ source. Moreover, in a case especially germane to the matter at hand with thélei and $\theta a$, Pappas, 1999 has discussed the increased separation of thélo: in futures from its corresponding past tense é:thela in its use in forming counterfactuals in Middle Greek.

Therefore, it would appear that "grammaticalization" does not need to be invoked as the force behind the ultimate formation of a grammatical morpheme for future in Greek. Well-understood processes of change other than "grammaticalization" suffice to give the ultimate result.

\section{Conclusion}

Thus, the answer to the "Process" Question is that Grammaticalization is not really a process. Rather, it is instead an epiphenomenon, an effect (as argued also by Janda, this volume). In this way, its status is somewhat like that of Lexical Diffusion, in that there is clearly a diffusionary effect in the way sound change is realized in lexical material, but one need not privilege Lexical Diffusion with the status of an independent "mechanism" of change — instead, the well-known mechanisms of analogy and dialect borrowing together can give the diffusionary effect that has been referred to as "Lexical Diffusion". ${ }^{14}$

Finally, the conclusions reached here have a bearing on the question of unidirectionality in grammaticalization. In particular, if grammaticalization is not a process, then it is not clear that there is anything to be gained by an insistence on unidirectionality as a hallmark of grammaticalization. Rather, some reversals on the grammaticality "cline" would be expected, just as analogy can be "bidirectional" (Tiersma, 1978) and can run counter to the usual pattern whereby the more frequent and more productive type is generalized; for example, English shows an innovative strong verb form dove competing now with the more regular, yet older dived, and the 
innovative $d$ warves with the irregular morphophonemic voicing in the plural competes with the more regular but older $d$ warfs, and Tiersma gives telling examples from Frisian. Thus, examples cited by Joseph and Janda, 1988; Campbell, 1991; Janda, 1995; Janda (this volume), and others of changes involving an item becoming less grammatical (e.g. French derrière 'behind' $\rightarrow$ noun 'buttocks', or the first person verbal affix -mos in New Mexico Spanish $\longrightarrow$ clitic nos (Janda, 1995)) provide compelling cases. Such instances have not been successfully countered, though discussed in Hopper and Traugott, 1993 and Traugott and Heine, 1991, for instance, where a potential for circularity creeps in, in that it is suggested that grammaticalization should be recognized only when there is adherence to the claim of unidirectional movement on the cline; if so, then unidirectionality becomes definitional, and not an empirical claim.

The overall thrust of these remarks is to cast doubt on grammaticalization as a process and as mechanism of language change, thereby suggesting that a framework such as "Grammaticalization Theory" is an unnecessary elaboration. It cannot be denied, though, that the investigation of grammaticalization has proven to be a fruitful and productive way of gaining insight into the workings of language change, even if a closer look at particular cases, as done here for Greek, shows it to be an epiphenomenon resulting from other processes of change, and thus reveals a picture of grammatizalization that is at odds with conventionally held views.

Address of author:

Department of Linguistics

222 Oxley Hall

The Ohio State University

Columbus, Ohio USA 43210-1298 


\section{Bibliography}

Anttila, R. (1972) An Introduction to Historical and Comparative Linguistics. MacMillan, New York.

Bânescu, N. (1915) Die Entwicklung des griechischen Futurums von der frühbyzantinischen Zeit bis zur Gegenwart. Königliche Hofbuchdruckerei F. Göbl Söhne, Bucharest.

Bybee, J., Pagliuca, W., and Perkins, R. (1994) The Evolution of Grammar: Tense, Aspect, and Modality in the Languages of the World. The University of Chicago Press, Chicago.

Bouchard, D. (1988) French voici /voilà and the analysis of pro-drop. Language 64, 89-100.

Campbell, L. (1991) Some grammaticalization changes in Estonian and their implications. In Traugott and Heine, eds, Vol. 1, pp. 285-299.

Dressler, W. (1966) Von altgriechischen zum neugriechischen System der Personalpronomina. Indogermanische Forschungen 71, 39-63.

Garrett, A. (1990) Hittite enclitic subjects and transitive verbs. Journal of Cuneiform Studies 42, 227-242.

Garrett, A. (1996) Wackernagel's Law and unaccusativity in Hittite. In Approaching Second: Second Position Clitics and Related Phenomena, eds A. Halpern and A. Zwicky, pp. 85-133. CSLI Publications, Stanford.

Haiman, J. (1991) From V/2 to subject clitics: evidence from northern Italian. In Traugott and Heine, eds, Vol. 1, pp. 135-57.

Hatzidakis, G. (1905) Meseoniká ke ná eliniká, A’, B’. Athens (reprinted (1989), Adolf Hakkert, Amsterdam).

Heine, B. and Reh, M. (1984) Grammaticalization and Reanalysis in African Languages. Buske, Hamburg. 
Herring, S. (1991) The grammaticaliztion of rhetorical questions in Tamil. In Traugott and Heine eds, Vol. 1, pp. 253-84.

Hopper, P. J. and Traugott, E. C. (1993) Grammaticalization. Cambridge University Press, Cambridge.

Householder, F., Kazazis, K., and Koutsoudas, A. 1964. Reference Grammar of Literary Dhimotiki. Indiana University Research Center in Anthropology, Folklore, and Linguistics, Bloomington / Mouton \& Co., The Hague.

Jaeggli, O. and Safir, K. (1989) The null subject parameter and parametric theory. In The null subject parameter, eds O. Jaeggli and K. Safir, pp. 1-44. Kluwer Academic Publishers, Dordrecht.

Janda, R. D. 1995. From agreement affix to subject "clitic"--and bound root: -mos $>-\boldsymbol{n} o s$ vs. (-)nos(-) and nos-otros in New Mexican and other regional Spanish dialects. Papers from the Parasession on Clitics, pp. 118-139. Chicago Linguistic Society, Chicago.

Janda, R. D. (This volume) Beyond "Pathways" and "Unidirectionality": On the Discontinuity of Language Transmission and the Counterability of Grammaticalization. Language Sciences.

Jeffers, R. and Zwicky, A. (1980) The Evolution of Clitics. OSU Working Papers in Linguistics 24, 55-64.

Joseph, B. (1981) On the Synchrony and Diachrony of Modern Greek na. Byzantine and Modern Greek Studies 7, 139-54.

Joseph, B. (1988) Modern Greek Pronominal Affixes: The Case Against Clisis. Papers from the 24th Regional Meeting of the Chicago Linguistic Society Vol. 1, pp. 203-215. Chicago Linguistic Society, Chicago.

Joseph, B. (1990) The Benefits of Morphological Classification: On Some Apparently Problematic Clitics in Modern Greek. In Contemporary Morphology, 
eds W. Dressler, H. Luschützky, O. Pfeiffer, and J. Rennison, pp. 171-181. Mouton de Gruyter, Berlin.

Joseph, B. (1992) Diachronic explanation: Putting speakers back into the picture. In Explanation in Historical Linguistics, eds G. Davis and G. Iverson, pp. 123-144. John Benjamins Publishing Co., Amsterdam.

Joseph, B. (1994) On Weak Subjects and Pro-Drop in Greek. In Themes in Greek Linguistics, eds I. Philippaki-Warburton, K. Nicolaidis, and M. Sifianou, pp. 2132. John Benjamins Publishing Co., Amsterdam.

Joseph, B. (Forthcoming) The Modern Greek Weak Weak Subject Pronoun tos - Its Origins and Implications for Language Change and Language Structure: A Study in Grammatical Change. To appear in Innsbrucker Beiträge zur Sprachwissenschaft series, Universität Innsbruck (2000).

Joseph, B. and Janda, R. (1988) The how and why of diachronic morphologization and demorphologization. In Theoretical Morphology, eds M. Hammond and M. Noonan, pp. 193-210. Academic Press, San Diego.

Kim, H. (1995) On the genitive of the Anglo-Saxon Deor. Neuphilologische Mitteilungen 96, 351-359.

Labov, W. (1994) Principles of Linguistic Change: Internal Factors. Blackwell, Cambridge (MA) and Oxford (UK).

Lehmann, C. (1982) Thoughts on Grammaticalization: A Programmatic Sketch, Volume 1. Arbeiten des Kölner Universalien-Projekts 48. Universität Köln, Köln.

Lehmann, C. (1985) Grammaticalization: Synchronic Variation and diachronic change. Lingua e Stile 20, 303-318.

Lord, C. (1976) Evidence for Syntactic Reanalysis: From Verb to Complmentizer in Kwa. In Papers from the Parasession on Diachronic Syntax, pp. 179-191. Chicago Linguistic Society, Chicago. 
Meillet, A. (1912) L'évolution des formes grammaticales. Scienta (Rivista di Scienza) 12, No. 26,6.

Mirambel, A. (1959) La langue grecque moderne. Déscription et analyse. Klincksieck, Paris.

Morin, Y.-C. (1985) On the two French subjectless verbs voici and voilà. Language 61, 777-820.

Morin, Y.-C. (1988) French voici and voilà: A reply to Bouchard. Language 64, 101-103.

Pappas, P. (1999) "From thelo: graphein/e:thela graphein to tha grapho:/tha egrapha: Comparing the development of futures and counter-factuals in Early Modern Greek". Ohio State University Working Papers in Linguistics 52.

Perlmutter, D. (1971) Deep and Surface Constraints in Syntax. Holt, New York.

Psicharis, J. (1884) Essai de Phonétique Néo-Grecque. Futur Composé du Grec Moderne. Imprimerie Nationale, Paris.

Sandfeld, K. (1930) Linguistique balkanique. Problèmes et résultats. Librairie Ancienne Honoré Champion, Paris.

Schaller, H. (1975) Die Balkansprachen. Eine Einführung in die Balkanphilologie. Winter, Heidelberg.

Steele, S. (1977) Clisis and Diachrony. In Mechanisms of Syntactic Change, ed C. Li, pp. 539-579. University of Texas Press, Austin.

Sturtevant, E. (1939) The Pronoun *so, *sa: *tod and the Indo-Hittite Hypothesis. Language 15, 11-19.

Thavoris, A. (1977) Morfolojiká merikón idiomáton tis ditikís makedonías. In A' Simbósio Glosolojías tu Vorioeladikú Xóru, pp. 75-95. Institute for Balkan Studies, Thessaloniki.

Thumb, A. (1910) A Handbook of the modern Greek Language. (Reprinted 1964, in English Translation: Argonaut Publishers, Chicago.) 
Tiersma, P. (1978) Bidirectional leveling as evidence for relational rules. Lingua 45, $65-77$.

Traugott, E. C. and Heine, B. eds. (1991) Approaches to Grammaticalization

Volumes 1, 2. John Benjamins Publishing Co., Amsterdam.

Zwicky, A. (1985) Clitics and Particles. Language 61, 283-305.

Zwicky, A. and Pullum, G. (1983) Cliticization vs. Inflection: English n't',

Language 59, 502-513.

"Versions of this paper have been given at a number of venues: the 7th Annual Meeting of the Formal Linguistic Society of the Midwest (FLSM) in Columbus in May 1996; the Annual Meeting of the Linguistic Society of America in Chicago in January 1997; the Department of Linguistics of the University of Canterbury (New Zealand) in June 1997; and elsewhere in even more divergent forms (focusing mainly on the first case discussed here). I thank all the audiences at these presentations, but especially Richard Janda, Elizabeth Traugott, Lyle Campbell, and Andrew Carstairs-McCarthy, for useful comments, and I have benefitted as well from discussion with Nick Nicholas. I assume responsibility for all errors and lapses.

${ }^{1}$ The first two examples are much discussed in the literature and so I give them without a specific source; the Ewe example is taken from Hopper \& Traugott, 1993, p. 14-16, who draw on Lord, 1976 for their discussion.

${ }^{2}$ I note, though, that the Ewe case seems to rest on the establishment of an etymological connection between the main verb and the complementizer and the assumption of historical priority for the verb, which, while reasonable, is different from the clear chronology in the English and Latin examples.

${ }^{3}$ I use the symbol $\langle\delta\rangle$ for the voiced interdental fricative in Greek.

${ }^{4}$ This is the well-known "Clitic doubling" or "Object Reduplication" phenomenon that has been discussed in the literature on the Balkan Sprachbund, e.g. in Sandfeld, 1930 and Schaller, 1975.

${ }^{5}$ Admittedly, not all speakers share this judgment; thus my argument may be restricted to just those speakers who show voicing here.

${ }^{6}$ It should be noted also that the definite article, the forms of which bear a striking but most likely adventitious resemblance to the emerging weak accusative form, was encroaching on the old relative pronoun, giving an innovative pronominal usage for accusative forms like tón.

${ }^{7} \mathrm{I}$ use $<\mathrm{s}>$ to transcribe the Hittite sibilant which sometimes is transcribed with a hachek, and a colon (:) to indicate the scriptio plena writing of vowels.

${ }^{8}$ I have no information about the earliest occurrence of tos, but assume, as do all who have considered this matter, that it is relatively recent. Note that if deictic ná is a borrowing from Slavic (one of the etymological suggestions given above) and if the emergence of tos is tied to ná, then tos necessarily is somewhat recent.

${ }^{9}$ I give pre-Modern forms in transliteration, rather than attempting to approximate the presumed pronunciation in a transcription.

${ }^{10}$ There are some modern dialects, e.g. Cypriot Greek, that retain final $-n$, as well as some forms in the standard language, e.g. the genitive plural in -on, that similarly show - $n \#$. It is likely that there have been several waves of the loss of final $-n$, with interim periods in which $-n \#$ was restored from the learnèd language and/or analogically reintroduced (e.g. if the loss began as a sandhi phenomenon).

${ }^{11}$ Indeed, the range of variability in the expression of the future tense in Medieval Greek texts is striking (and there are other formations that do not involve a form of thélo: that are not mentioned here). The various types described here cooccur in texts, though there is a clear chronology to the emergence of the different forms, as outlined by Bânescu, 1915.

${ }^{12}$ Actually, hina in (21) is a bit anachronistic, since by the time it was introduced into the future tense formation, it was probably already [na], and [na] developed from earlier hina by regular sound changes; the representation of the Greek here is given in more of an approximation of the pronunciation since in this form the future is now approaching Modern Greek.

${ }^{13} \mathrm{Clitic}$ pronouns at this stage were positioned between thélei and the main verb, e.g. thélei to grápho: 'I will write it', and never occurred as a proclitic to thélei (**to thélei grápho:). See Joseph, 1978/1990, p. 143-145, for examples and discussion. 
${ }^{14}$ This view is undoubtedly somewhat controversial, especially in view of the discussion in Labov, 1994 concerning Lexical Diffusion, and his doubts that dialect borrowing is responsible for some putative cases of Lexical Diffusion. However, I would say that until it can be shown that intra-speaker analogical spread of a new variant from one alternating form to another and inter-speaker (dialect) borrowing cannot account for the piece-meal spread of a sound change, the range of possible mechanisms of change should not be expanded to include Lexical Diffusion as a new type. 